\title{
Teachers' perceptions of integrating kindergarten and first-grade primary school language curricula
}

\author{
Zoi Apostolou', Nektarios Stellakis ${ }^{2}$
}

\begin{abstract}
The purpose of this research paper is to investigate the perceptions of kindergarten teachers and first-grade primary school teachers on the integration of kindergarten and first-grade of primary school language curricula. This research is part of a broader study of the relation between natural/early and conventional/school literacy, the teachers' perceptions of the possibility of integration of language curricula, as well as practices resulting from the study of curricula. The data were collected through a questionnaire sample of 326 kindergarten teachers and 306 teachers who were teaching at the time of this study the first-grade of primary school in two Greek prefectures. Research data has shown that first-grade teachers appear to be more positive than kindergarten teachers towards integrating the two curricula. Both kindergarten teachers and first-grade teachers seem to partially agree with the creation of a curriculum with common goals and objectives. Nevertheless kindergarten teachers appear more hesitant, expressing their concerns and fears of a potential "schoolarization" of the kindergarten.
\end{abstract}

\section{Article History}

Received: 20 January 2020

Accepted: 29 April 2020

Keywords

Literacy; Kindergarten;

Primary school; Teachers

perceptions; Integration;

Curricula

\section{Introduction}

In recent years, the issue of enhancing child literacy has been a growing concern for the international community. Literacy has been shown to be linked to the subsequent school success or failure of the child and can therefore contribute in the end to social well-being, social justice and the development of democracy (United Nations Educational, Scientific and Cultural Organization [UNESCO], 2005, 2007, 2015). According to the UNESCO (2004), literacy is defined as:

The ability to identify, understand, interpret, create, communicate and compute, using printed and written materials associated with varying contexts. Literacy involves a continuum of learning in enabling individuals to achieve their goals, to develop their knowledge and potential, and to participate fully in their community and wider society (p.21).

Interdisciplinary research in recent decades has greatly expanded the scope of mastering literacy, adding new data on children's familiarisation with literacy and leading to a revision of it, regarding how literacy is enhanced and how language is taught. Research conducted internationally (see for example: Heath, 2009; Hindman and Wasik, 2011; Powell, Diamond, Bojczyk and Gerdel, 2008; Scull, Nolan and Raban, 2013; Snow, Burns and Griffin, 1998; Strickland and Shanahan, 2004; Zeegers, 2012; Zhu, 2010) but also in Greece (see for example: Aidinis and Grollios, 2007; Giannikopoulou, 2001; Kondyli and Stellakis, 2006; Papoulia-Tzelepi, 2001; Porpodas, 2002; Tafa, 2001; Xefteri, 2017) demonstrates that early language stimulation have great importance for reading development and children's literacy learning occurs through actions that have a meaning for them and a clear purpose. Various pedagogical, social, and psychological factors interact and influence learning to read and write, reflecting on the drafting of Greek curricula, related school textbooks, and the theoretical and methodological approaches proposed by

${ }^{1}$ University of Patras, Department of Educational Science and Early Childhood Education, Division of Social Theory and Analysis, Greece, e-mail:apostolo@upatras.gr, ORCID: https://orcid.org/0000-0003-4359-397X

${ }^{2}$ University of Patras, Department of Educational Science and Early Childhood Education, Division of Social Theory and Analysis, Greece, e-mail:nekstel@upatras.gr, ORCID: https://orcid.org/0000-0002-1934-8715 
them for kindergarten ${ }^{1}$ (4-6 years) and primary school ${ }^{2}$ (6-12 years). Curricula set out the purposes and goals of education, the specific objectives, the fundamental pedagogical principles, the content, the methods of teaching and learning, the indicators of success and modes of assessment, the learning environment, school-family relationships and some complementary activities (Alahiotis, 2002). In Greece, for kindergarten (4-6 years old), Cross-thematic Curriculum Framework for Kindergarten (hereafter referred to as CTC) (Ministry of Education/Pedagogical Institute [MoE/PI], 2002b) is the curriculum and Preschool Teacher's Guide (hereafter referred as PTG) (Dafermou, Koulouri and Basagiannis, 2006) ${ }^{3}$ consist the basic tool for kindergarten teachers. For first-grade of primary school (6-7 years old), Crossthematic Curriculum Framework for Greek Language of Compolsury Education ${ }^{4}$ (MoE/PI, 2002a) is the curriculum, Teacher's Book for Teaching Language in First-grade ${ }^{5}$ (MoE/PI, 2008b) is the guideline book for teaching language at first-grade and Student's Book for First-grade ${ }^{6}$ (MoE/PI, 2008a) is the textbook for the students.

The study of the objectives of the Greek curricula of the kindergarten and the first-grade of the primary school on the language module indicates reference to modern teaching approaches, such as the holistic approach, emergent literacy, the communicative approach and functional use of language. The conflict between traditional skills based approach, focusing on code understanding and the whole language approach that focuses on meaning has led to the adoption of a balanced / equilibree approach model (see for example: Aidinis and Nunes, 2001; Comber and Nichols, 2004; Morris, 2015; Pearson, Raphael, Benson and Madda, 2007; Pressley, 2002; Xue and Meisels, 2004) which tries to combine the best elements from other approaches. Xue and Meisels (2004, p.222) state that "in order to learn to read effectively, children

\footnotetext{
${ }^{1}$ In Greece, Preschool education connected to primary education: Law 1566/1985 stipulated that preschool education belong to primary education (children 6-12 years old); a great part of its operation follows the same legislative regulations that are in force for primary schools. Specifically, early childhood education is provided in kindergartens, which operate independently or in centres together with state primary schools for children aged 4-6. Since September 2007, under the provisions of Law 3518/2006, the second year of childhood education is compulsory for young children who have completed their fifth year of age by 31st December of their enrollment year. Most kindergartens are state-run, while the number of private ones is quite limited. Since 1984, preschool teachers trained at university departments of education, a fact that has contributed to elevating the status of early childhood education (Sofou and Tsafos, 2009).

${ }^{2}$ In Greece, Primary education lasts six years (6-12). Children who turn six by December 31 can enroll in the first grade. Attendance is obligatory. Cross Thematic Curriculum Framework for Compulsory Education (DEPPS) organised into 6 levels, each of them corresponding to one (1) out of six (6) primary school grades. The teaching subjects of primary school are Religious Education, Language, Mathematics, History, Study of the Environment, Geography, Natural Sciences, ICT, e.t.c. Modern Greek Language at firstgrade is teaching for 9 hours per week (European Commission [EC], 2019).
}

${ }^{3}$ The preschool CTC provides instructions for planning and developing activities in the following five school learning areas: Language, Mathematics, Environment Studies, Creation and Expression (through Fine Arts, Drama, Music, Physical Education) and Computer Science. According to the CTC, these learning areas not conceived as independent subjects for independent teaching. Instead, the teachers consider these areas when planning and implementing meaningful and purposeful activities for the children. Thus, 3 years after curriculum's publication in the Government journal in 2003, the MoE/PI published a 431 page-long book, the Preschool Teacher's Guide (hereafter referred as PTG) (Dafermou et al., 2006). The PTG contains theoretical and methodological support, guidelines on the teaching of the five learning areas described above and good practice examples of development and planning of activities. PTG included a separate chapter for Literacy (Sofou and Tsafos, 2009).

${ }^{4}$ In line with lifelong learning literacy theory, the aim of teaching Greek Language in Primary school is to develop pupils' abilities to communicate effectively in speech and writing, in order to participate confidently in school and public life (MoE/PI, 2002a). To achieve this aim an eclectic approach to language is attempted, combining elements from different language theories on the basis of teaching and learning needs. The curicullum includes guiding principles (Oral Speech: Speaking and listening, Written speech: Reading, Written speech: Handwriting and producing written discourse, Literature, Vocabulary, Grammar, Information management) and general goals for these principles (MoE/PI, 2002a).

${ }^{5}$ The Teacher's Book for Teaching Language in First-grade contains texts and appropriate activities for the processing of these texts, which concern the main axes, as well as the categories of the teaching objectives of the Curriculum of the Language Studies for the Primary School (MoE/PI, 2008b).

${ }^{6}$ School textbooks have been elaborated based on National Curricula, applicable to all subjects, grades and education levels. They are distributed free of charge to pupils across the country (EC, 2019). 
Teachers' perceptions of integrating kindergarten...

need a balanced instructional approach that includes learning to break the code and engaging in meaningful reading and writing activities". Within this theoretical framework, the primary school language curriculum cannot ignore and underestimate the experiences and knowledge children have acquired in the family environment and in the kindergarten. School literacy is a continuation of the early / natural literacy (Hasan, 2006; Matsagouras, 2007), not only because it is subsequent, but because school literacy must be built on the basis of natural literacy, since natural and school literacy are not distinct stages but adjacent parts of a continuous (Kondyli and Stellakis, 2006).

Within the framework of adopting a balanced approach to literacy, an important supporting factor is the continuation of the culture, traditions and learning experiences that children experience both in kindergartens and in primary schools (Broström, 2002; Fabian and Dunlop, 2006). In line with lifelong learning literacy theory (see for example: Djonov, Torr and Stenglin, 2018; Education, Audiovisual and Culture Executive Agency [EACEA], 2011; Hanemann, 2015, 2019; Hanemann and Krolak, 2017; Kennedy et al., 2012; Silva Joyce and Feez, 2016; UNESCO Institute for Lifelong [UIL], 2010, 2017, 2018; UNESCO, 2005, 2007, 2015, 2017; Xue and Meisels, 2004) mastering literacy is an ongoing process and smooth transitions of students from one level to another can be greatly facilitated if educators from one grade, for example the pre-primary school, cooperate with those of the next grade, that is, the primary school, and vice versa (Bredekamp and Copple, 1997; O'Sullivan, 2005). Kindergarten teachers and firstgrade teachers must exchange curriculum information and modify it appropriately so that the curriculum can exhibit continuity, and children can continue their learning process and achieve greater future progress (Department of Education and Early Childhood Development [DEECD], 2009). Only in such a framework of shared approaches, perceptions and practices can the pupils work and continuity not be interrupted (Broström, 2002; DEECD, 2009; EACEA, 2011; Fabian and Dunlop, 2006; Frank-Oputu and Oghenekohwo, 2017; Hanemann, 2015, 2019; Hanemann and Krolak, 2017; Neuman, Snow and Canizares, 2000; National Institute of Child Health and Human Development Early Child Care Research Network [NICHD], 2005; O'Sullivan, 2005; UNESCO, 2017; Wasik, Bond and Hindman, 2006; World Education Forum [WEF], 2000).

According to the basic goal of CTC for kindergarten, preschool education in Greece is an integral part of our educational system (Dafermou et al., 2006; MoE/PI, 2002b) and therefore, national planning of a structured transition from pre-primary to primary school seems more important than ever. Therefore, the question arises of the need to integrate the two programs, kindergarten and first-grade, in particular as regards the language learning area. The adoption of a common pedagogical approach, common pedagogical and theoretical principles, objectives, content, teaching and learning methods, a comparable learning environment in the two curricula, delineate the concept of the integration of the two programs. Serving common goals in the light of a balanced approach and enhancing natural literacy could help to remove the potential discontinuity between curricula. In this context, a successful balanced approach to literacy requires the teacher on one hand to combine approaches, methods and techniques to become more effective for his students and on the other hand to stay informed, to train and collaborate (Hall, 2003). Collaboration between kindergarten and primary school teachers is considered as one of the most important factor in confronting the difficulties of the transition (Ackesjö, 2013; Alatalo, Meier and Frank, 2017; Broström, 2007; Dockett and Perry, 2007; Karydis, 2014; O'Sullivan, 2005; Sivropoulou and Vrinioti, 2009) as "the continuity" between the two educational institutions related directly with the development of normal transition (see for example: Dunlop and Fabian, 2002; Zeegers, 2012; Zhu, 2010).

In Greece, research focusing on the study of curricula and the perceptions of kindergarten teachers and first-grade primary school teachers on their teaching approaches, their collaboration and the transition is extremely limited. In particular, no research has been found in the Greek area concerning the perceptions of kindergarten teachers and first-grade primary school teachers about the integration of the two programs, as well as their interrelations. This research gap, identified in international and Greek literature, is what this paper seeks to address. 
Method

\section{The purpose of the study}

The purpose of this research is to study the perceptions of preschool and early primary school teachers on the relationship between early / primary and conventional / school literacy, and in particular on the feasibility of integrating the two curricula and how they believe that unification could contribute to the optimization of the language teaching approach at both levels or the reasons for their disagreement with such a unification. We are going to deal with the answer to the following research questions:

(a) What are the teacher's perceptions (agreement/disagreement) about the potential integration of the two curricula?

(b) Which are the reasons of their agreement/disagreement about the potential integration of the two curricula and how they believe that integration could optimize the approach to language teaching at both levels (what teachers think about young learner's adjustment to primary school if there existed a common methodological approach to language teaching at both levels)?

\section{The methodology of the study}

The present research was conducted using a self-fulfilling electronic questionnaire (SurveyMonkey) (Bryman, 2017; Cohen and Manion, 2008; Creswell, 2016; Iosifidis, 2003; Robson, 2010). The self-administered questionnaire was organized in some study areas (knowledge of curricula, perceptions of the methodology of language teaching as suggested by the curricula, perceptions of the collaboration of kindergarten teachers and teachers of the first-grade of primary school, language teaching practices, perceptions of the unification of curricula) with closed and open-ended questions. These areas and questions were developed based on the theoretical framework of a broader research (a thesis). The questions were developed to answer the research questions of each axis. For the purposes of this paper, we will present the 8th axis of the questionnaire which examines the degree of agreement of teachers regarding the integration of the language curricula of kindergarten and first-grade or the first two grades of primary school. Questions (according to the topic of this paper) included in the questionnaire were:

(a) a closed-ended question: "Do you agree or disagree with the integration of the language curriculum of the kindergarten and first-grade or the first two grades of the primary school?"

(b) an open-ended question: "Identify why (the reasons) do you agree or disagree with the integration of the two curricula of kindergarten and first-grade or the first two grades of primary school (1st part) and how you think integration could help optimize (or not) the approach to language teaching at both levels, or the reasons for your disagreement (2nd part)?"

With the open-ended question, the respondents were asked to answer or comment on them in a way that they think best (Cohen, Manion and Morrison, 2007, p.321) with the purpose of investigating and understanding in depth the stated agreement / disagreement.

To process data, the techniques used were the quantitative for the closed-ended question and content analysis for the open-ended question. The collected research data from the closed-ended question were categorized into classification and tables and then coded and entered into the statistical program SPSS 25.0 (Statistical Package for the Social Sciences) for analysis with descriptive statistics (frequency distribution tables) (Bryman, 2017; Creswell, 2016) in two categories:

(a) agreement with the unification of the language curriculum of the kindergarten and first-grade or the first two grades of the primary school.

(b) disagreement with the unification of the language curriculum of the kindergarten and firstgrade or the first two grades of the primary school. 
For the open-ended question (for both 1st and 2nd part) we used content analysis, with the content of the sentence/phrase as a unit of analysis (Creswell, 2016) for the written text. The various units of analysis that were highlighted were classified in a specific category of analysis. Sentences are taken as the units of analysis, which are according to their semantic meaning (Koustourakis, 2014; Neves and Morais, 2001). The sentences were placed into one of the following 9 categories of analysis (for both 1st and 2nd part of open-ended question) that emerged from the objective and the theoretical framework of the specific research (Table 1). The first five (1-5) categories of analysis concern the answers of those who seemed positive towards the integration, while the last four (6-9) concern those who seemed negative towards the integration of the two curricula.

Table 1. Categories of content analysis for the open-ended question

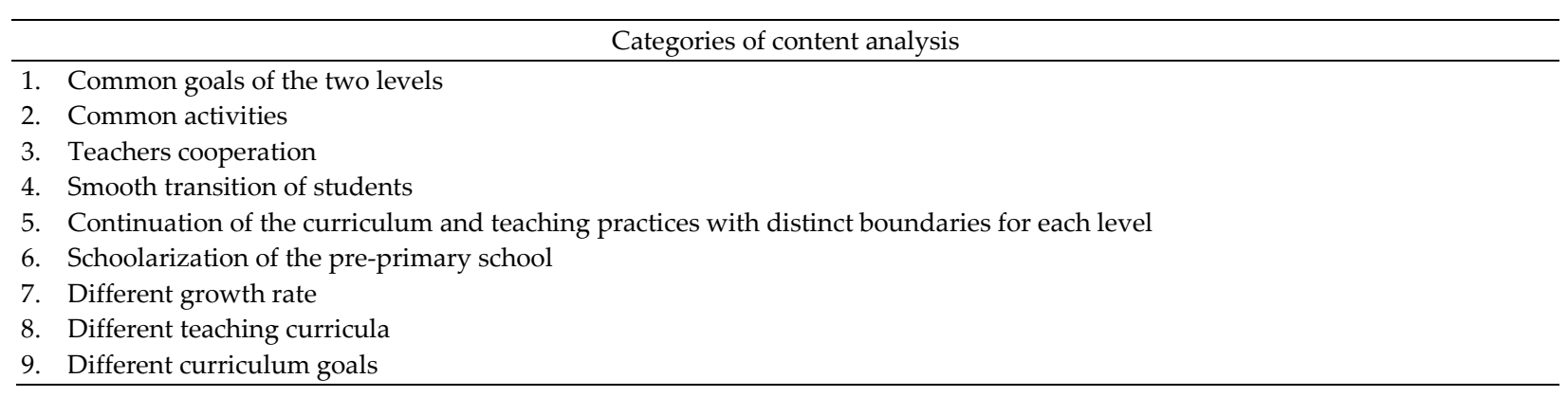

In designing and conducting the research we have taken into account ethical issues and ethics, by requesting permission and consent from MoE/PI (Bryman, 2017; Cohen and Manion, 2008). The questionnaires were accompanied by a letter stating the purpose of the research, the value of participation, the anonymity of participants and that the results of the research will be informed. Further, the collected information from each participant was assigned pseudonyms (numbers) as part of concealing participants' identities. Confidentiality was observed by assigning passwords to files of softcopy data, and unauthorized person had no access to the collected hard and softcopy data (Bryman, 2017; Cohen and Manion, 2008).

\section{The sample of the study}

The study involved 632 teachers, 326 kindergarten teachers (Greek kindergartens) and 306 teachers teaching the year of the process in the first-grade (Greek primary schools) in the prefectures of Achaia and Ilia (the population was 488 kindergarten teachers and 380 first-grade teachers). The questionnaire was sent electronically (SurveyMonkey7) to the entire population and the survey sample for those kindergaten teachers and first-grade teachers who responded to it (Cohen and Manion, 2008; Creswell, 2016). However, the sample size and the geographical limitation of the survey did not allow us to generalize the results. There may be differences in their perceptions and practices from region to region. The findings of this research (although not generalizable) are representative of teachers' perceptions of the issue under consideration. Nevertheless, we believe that the findings should not lose their relevance but should serve as a basis for further relevant investigations.

In terms of gender, $243(79.4 \%)$ teachers (Table 2$)$ are women and $63(20.6 \%)$ are men, while 325 $(99.7 \%$ ) kindergarten teachers (Table 3 ) are women. $85 \%$ of teachers and $88.3 \%$ of kindergarten teachers 8 have completed basic studies (University or Pedagogical Academy and Simulation Degree), while 15\% of teachers and $11.7 \%$ of kindergarten teachers have additional studies (Retraining and/or Postgraduate and/or Doctorate). Teachers (88.2\%) and kindergarten teachers (84\%) hold permanent teaching positions. $43.1 \%$ of teachers have been teaching for $0-10$ years, $30.4 \%$ for $11-20$ years, while $26.5 \%$ for more than 20 years, whereas in cases of teachers of the same school, most have been teaching less than 10 years.

\footnotetext{
${ }^{7}$ SurveyMonkey is an online survey software allows you to launch any kind of online survey project.

${ }^{8}$ It is worth noting that in Greece, both kindergarten teachers and teachers of primary schools receive equivalent university education and there is a uniform pay for all teachers in the Greek public sector.
} 
Regarding kindergarten teachers, $50.6 \%$ have been teaching for $0-10$ years, $31.8 \%$ for $11-20$ years and $17.6 \%$ for more than 20 years. $91.8 \%$ of teachers work in classical primary schools, with $48.7 \%$ of them located on the same premises as kindergartens. 244 (74.8\%) kindergarten teachers work in two-grades kindergartens and $82(25.2 \%)$ teach in small one-grade kindergartens in the two prefectures, with 151 $(46.3 \%)$ being co-located with primary schools. 181 (59.2\%) teachers and $182(55.8 \%)$ kindergarten teachers work in urban schools, while $20 \%$ of teachers and kindergarten teachers work in semi-urban or rural schools (rural areas).

Table 2. Individual characteristics of First-grade Primary school teachers

\begin{tabular}{lccrccccccccc}
\hline \multicolumn{10}{c}{ First-grade Primary school teachers } \\
\hline & \multicolumn{10}{c}{ Gender } & \multicolumn{1}{c}{ Education } & \multicolumn{2}{c}{ Years of service } & \multicolumn{2}{c}{ Region of School } & \multicolumn{3}{c}{ Co-located schools } \\
\hline & Male & Female & Basic & Additional & $0-10$ & $11-20$ & $>20$ & Urban & Semi-urban & Rural & Yes & No \\
\hline Frequency & 63 & 243 & 260 & 46 & 132 & 93 & 81 & 181 & 63 & 62 & 149 & 157 \\
$\begin{array}{l}\text { Percentage } \\
\text { (N) }\end{array}$ & 20,6 & 79,4 & 85 & 15 & 43,1 & 30,4 & 26,5 & 59,2 & 20,6 & 20,3 & 48,7 & 51,3 \\
\hline
\end{tabular}

Table 3. Individual characteristics of Kindergarten teachers

\begin{tabular}{lcccccccccccc}
\hline \multicolumn{10}{c}{ Kindergarten teachers } \\
\hline & \multicolumn{1}{c}{ Gender } & \multicolumn{1}{c}{ Education } & \multicolumn{3}{c}{ Years of service } & \multicolumn{2}{c}{ Region of } & School & \multicolumn{3}{c}{ Co-located schools } \\
\hline & Male & Female & Basic & Additional & $0-10$ & $11-20$ & $>20$ & Urban & Semi-urban & Rural & Yes & No \\
\hline Frequency & 1 & 325 & 283 & 43 & 165 & 103 & 58 & 182 & 75 & 69 & 175 & 151 \\
$\begin{array}{l}\text { Percentage } \\
\text { (N) }\end{array}$ & 99,7 & 0,3 & 88,3 & 11,7 & 50,6 & 31,8 & 17,6 & 59,6 & 23,0 & 21.2 & 53,7 & 46,3 \\
\hline
\end{tabular}

In the following section the research results are presented and analyzed.

\section{Results}

The presentation of the research findings, which refers to the quantitative and content analysis of the research material that emerged from the answers at the questionnaires with Greek pre-primary and first-grade primary school teachers' in the the prefectures of Achaia and Ilia, takes place in accordance with the categories of analysis outlined above.

\section{Results of closed-ended question: Agreement and disagreement with the integration of the two curricula}

Greek pre-primary and first-grade primary school teachers' perceptions on the integration of preprimary and first-grade language curricula appear to fall into two categories. On the one hand are those who (partially) agree with the integration, and on the other hand are those who strongly disagree. In particular, answering the closed-ended question "Do you agree or disagree with the integtation of the language curriculum of the kindergarten and first-grade or the first two grades of the primary school?" 190 kindergarten teachers $(58.3 \%)$ agree and $136(41.7 \%)$ seem to disagree. 228 first-grade primary school teachers $(74.5 \%)$ seemed to agree, while only $78(25.5 \%)$ disagreed with integration (Table 4$)$. In fact, this differentiation between kindergarten teachers and teachers is statistically significant (Cramer's $V=0.171, x^{2}=18,560, \mathrm{df}=$ $1, \mathrm{p}<0.001)$.

Table 4. Agreement and disagreement of first-grade teachers and kindergarten teachers

\begin{tabular}{|c|c|c|c|c|}
\hline & \multicolumn{2}{|c|}{ Kindergarten teachers } & \multicolumn{2}{|c|}{ First-grade primary school teachers } \\
\hline & Agree & Disagree & Agree & Disagree \\
\hline Frequency & 190 & 136 & 228 & 78 \\
\hline Percentage & 58,3 & 41,7 & 74,5 & 25,5 \\
\hline$(\mathrm{N})$ & & & & \\
\hline
\end{tabular}

Kindergarten and First-grade teacher's results of open-ended question (1st part): Why agree or disagree with the integration of the two curiccula

Regarding the 1st part of open question "Identify why (the reasons) do you agree or disagree with the 
Teachers' perceptions of integrating kindergarten...

integration of the two curricula of kindergarten and first-grade or the first two grades of primary school", 142 $(43.3 \%)$ of the kindergarten teachers and $75(24,5 \%)$ of the first-grade primary school teachers answered, as they were optional. Initially the responses were categorized (in line with the categoris presented in Table 1) into agreement, disagreement with curriculum integration as well as some unclassified (Table 5).

Table 5. The reasons for agreement or disagreement with the integration of curricula (a)

\begin{tabular}{|c|c|c|c|c|c|c|}
\hline & \multicolumn{3}{|c|}{ First-grade primary school teachers } & \multicolumn{3}{|c|}{ Kindergarten teachers } \\
\hline & Agree & Disagree & Unclassified & Agree & Disagree & Unclassified \\
\hline Frequency & 50 & 24 & 1 & 85 & 51 & 6 \\
\hline Percentage & 66,67 & 33,33 & 1,33 & 59,86 & 35,92 & 4,23 \\
\hline$(\mathrm{N})$ & & 75 & & & 142 & \\
\hline
\end{tabular}

Next, in order to categorize the responses, their analysis was carried out based on categories that emerged from the answers themselves, which were re-sorted into the original agreement / disagreement categories. Of the $142(43.3 \%)$ kindergarten teachers that responded, 85 appeared to favor integration, while 51 when answering this optional open-ended question appeared to be opposed to integration of the curricula, expressing their fears and concerns. Of the 75 (24.5\%) first-grade primary school teachers who answered, 50 seem to be in favor of integration, while 24 appear to be opposed to integration of curricula. Six of these responses provided by kindergarten teachers and one by a teacher did not fall into either of the two categories (Table 6). They referred to the reasons of their aggrement (common goals, common activities, cooperation, smooth transition, continuity) or disagreement (schoolarization, different growth rate, diffeent curricula, different goals). Their answers are presented in more details to the next part of results, as these are directly related to the findings of the 2 nd part of the open-ended question and explain their agreement or disagreement.

Table $6{ }^{9}$. The reasons for agreement or disagreement with the integration of curricula (b)

\begin{tabular}{|c|c|c|c|}
\hline \multicolumn{2}{|c|}{ Kindergarten teachers } & \multicolumn{2}{|c|}{ First-grade primary school teachers } \\
\hline Agree & Disagree & Agree & Disagree \\
\hline Common goals (10) [8] & Schoolarization (40) [6] & Common goals (3) [13] & Schoolarization (9) [4] \\
\hline Common activities (13) [9] & Different growth rate (3) [12] & Common activities (1) [5] & Different growth rate (11) [4] \\
\hline Cooperation (9) [9] & Different curricula (3) [17] & Cooperation (10) [7] & Different curricula (3) [4] \\
\hline Smooth transition (8) [13] & Different goals (5) [8] & Smooth transition (3) [4] & Different goals (1) [9] \\
\hline Continuity (45) [1] & & Continuity (33) [5] & \\
\hline Total 85 & Total 51 & Total 50 & Total 24 \\
\hline \multicolumn{2}{|c|}{ Unclassified (6) } & \multicolumn{2}{|c|}{ Unclassified (1) } \\
\hline \multicolumn{2}{|c|}{ Total 142} & \multicolumn{2}{|c|}{ Total 75} \\
\hline
\end{tabular}

\section{Kindergarten teacher's results of open-ended question (2nd part): How integration could (or not) optimize the approach to language teaching at both levels}

Theacher's answers to the 2nd part of the open question "How integration could (or not) optimize the approach to language teaching at both levels?" are presented below through some indicative responses of kindergarten teachers and first-grade primary school teachers. These answers categorized ${ }^{10}$ according to the ways they propose to optimize the language teaching approach on both levels, are presented below.

Kindergarten teachers who respond that integration could optimize the approach to language teaching at both levels (Table 7), refer to:

\footnotetext{
${ }^{9}$ Next to each category is the number of replies categorized in it. In [ ] indicated the number of responses received in this category as the second, third or subsequent choice of respondents.

${ }^{10}$ Analysis categories for the 2nd part of the open-ended question are the same as those of the 1st part but these are presented here in more detail.
} 
Table 7. How the integration could optimize the approach language (KT)

Categories of content analysis for the second part of open-ended question

(a) the existence of a common Language Curriculum and Study Guide, "continuity" of the lesson objectives, common goals, common language teaching hours and joint activities.

(b) smooth transition of children from kindergarten to primary school through the adoption of a joint curriculum (the creation of a common framework) and joint language activities, interactive linguistic approaches that will arouse the interest of children on both levels, with separate boundaries for each grade, the joint organization of activities and the joint participation in school events.

(c) collaboration, exchange of views by educators, expansion of knowledge, mutual support, (educational) continuation of teaching practices, joint seminars, mutual knowledge of both curricula, sequenced goal-setting, co-housing of kindergartens and primary schools for the purposes of cooperation and continuity.

(d) support by both levels school counselors.

These categories aim to a common approach of language for the two levels with some possible differentiations due to age variation. İn particular, the integration of the two curricula for kindergarten teachers mainly concerns the continuity (a) and smooth transition of children from kindergarten to primary school through the adoption of a joint curriculum and joint activities (b). Characteristically a kindergarten teacher said:

There should be a common curriculum (in some areas) of the kindergarten and the primary school as long as the toddler is not deprived of certain activities that only in the kindergarten there is the time and the appropriate climate to carry out. Because there are some differences regarding the priorities of the kindergarten and those of a primary school $(\mathrm{KT} 1)^{11}$,

The integration of kindergarten and first-grade primary school curricula would provide a common practice in language teaching, reducing inconsistencies in the content but also in the methodology of language teaching (KT2). stating:

Kindergarten teachers seem to place a great deal of emphasis on the playful nature of learning,

There must be collaboration between kindergarten teachers and first-grade teachers, and goals that will be analyzed by both sides, without the kindergarten becoming a "school grade". Play is dominant in kindergarten (KT3).

The results of the integration of the two programs, according to the kindergarten teachers, would be particularly effective for the children $(b)$ :

By integrating curricula, the children will learn from the beginning a common way of approaching language teaching and there will be no confusion in their transition from one grade to the next ", " In preschool, infants have the opportunity to consolidate linguistic concepts that lead to school success, so the teacher "builds" on what was constructed in the kindergarten (KT4).

A kindergarten teacher also point to the effectiveness of integration for themselves (c):

Kindergarten teachers would be less pressured to systematically teach the alphabet by parents and teachers, and teachers would be less demanding (KT5).

As far as teachers are concerned, the only references (a) made by kindergarten teachers concerning their work are the following:

The primary school curriculum needs to be a continuation of kindergarten one. Teachers need to know what children have achieved from kindergarten so they can continue and not start assuming that children have the same starting point (KT6).

There is a clear reference to the need for primary school teachers to cooperate with kindergarten teachers (a and c) from a kindergarten teacher:

I think that to some extent it is already integrated. I believe that it would be better for it to only apply to the kindergarten and first-grade of primary school because these two stages are when children are essentially introduced to literacy. It would ensure, on an official level, continuity between the two levels for the benefit of the students, without, of course, removing the need for cooperation between teachers. However, I consider the choice of a different methodology to meet the special needs of the preschoolers a precondition (KT7).

Kindergarten teachers referred to parents' expectations and concerns about language teaching (c),

${ }^{11}$ Kindergarten teachers will be marked with KT and primary school teachers with PT and a number for each of them. 
Teachers' perceptions of integrating kindergarten...

which seem to affect their predisposition but also to some extent shape their work:

Creating a common framework and thus facilitating children's understanding of how it works, continuity between the two grades, reassuring parents that they will participate and understand the language goals (KT8).

The following statement of a kindergarten teacher includes all of the above ( $a, b, c$ and $d)$ :

On basic principles there could be set certain common goals to promote the building of language teaching, always taking into account the particularities of children's age, through curricula that will not schoolarize the kindergarten, but will transfer to the first-grade of primary school elements of the kindergarten (mostly learning in a playful way), so that the transition from one grade to another is smooth and enjoyable for children. The adoption of common elements in curricula would enhance the smooth transition of children and would set more specific goals without leaving the implementation of any of the programs being carried out, to an opportunistic and nontestable application of it. I find it essential to integrate into individual goals, always prioritizing the smooth transition that will help children, also giving teachers the opportunity to continue the educational process, without thinking only of what the parents want and ask for (KT9).

Kindergarten teachers who disagree with integration (Table 8) refer to:

Table 8. How the integration could not optimize the approach language (KT)

Categories of content analysis for the second part of open-ended question

(a) the different developmental level, the different learning abilities of kindergarten children compared to primary school children.

(b) the different approach to language teaching, the differentiation between the goals of the curricula and the working methods for the kindergarten and first-grade, different learning goals and "different interests, even between two so close ages, different linguistic and mental maturity".

(c) they emphasize socialization, teamwork, collaboration, spontaneous involvement of the child with the language; also the emerging, free and spontaneous character of literacy approach in kindergarten, but they mostly express their fear for a schoolarization of the kindergarten.

Kindergarten teachers express their fears and worries about the diefferent developmental level (a and b):

Learning abilities and perception rates are different at every age level. To "blackmail" a 4-year-old to climb linguistically and cognitively in order to reach higher linguistic goals before he has matured phonologically is not right. Language is not autonomous, and is determined by the psycho-emotional needs of preschoolers, which are at a different level from that of first or second grade primary school children. That is why, in my opinion, the two curricula should not be integrated, because phonological conquest from grade to grade requires different goals, methods and evaluation. Something I think an integrated curriculum cannot achieve (KT10),

I disagree because I don't want kindergarten to be a miniature primary school. The preschool plays an important role and should not be turned into a hardcore school where children will act as soldiers for the sole purpose of acquiring skills that will help teachers in their work. On the contrary, I firmly believe that, if teachers were trained to transmit the love for knowledge through activities (like kindergarten teachers), education would have another impetus in the Public Education System. Teachers who teach in the first-grades of primary school must pass special exams and work with preschool counselors (KT11).

They dispute (c):

If consolidation happens, I am afraid that the kindergarten will lose its current purpose and will be schoolarized. Up until now, unfortunately, only kindergarten teachers have taken the initiative faced with indifferent teachers (KT12),

and express their fears about the playful nature of the kindergarten that will be lost (c):

Tthe teaching of the language subject in the first-grade is based on mechanisms of knowledge and continuous repetition, while in the kindergarten it is emerging, freer and spontaneous, this stops with the introduction of children into primary school and systematic teaching. In no case should the kindergarten become primary school; however the first-grades of primary school should be like a kindergarten. Learning through play (KT13).

Another kindergarten teacher, condensing the above ( $a, b$ and $c)$, says:

I believe that integration should be for three years: from kindergarten to 2 nd grade. The teachers of the two levels should work together and of course the teachers should keep a portfolio, not just the "grades book". In fact, I think it would be more effective if the portfolio was the same from the beginning of the child's education in kindergarten. Then the teacher of the 1st and 2nd grade would update it. Then it would make sense for this portfolio to exist, which no one is paying attention to now ... I think it would be useful if, at least in first-grade, teachers created a few 'corners' in their classrooms. For example, they could have a mat for students to sit there to read their fairy tales or to be the talking circle or even a couple of kindergarten tables, like an "artist's bench"! ... They should also make the 


\section{Zoi APOSTOLOU \& Nektarios STELLAKIS}

most of the flexible zone's time for an approach to language by creating children's stories, poems, limericks, posters or advertisements ... and so much more ... Through the implementation of school activity programs, or other educational programs, the kids would have the ability to work together as a team and inevitably use the language in all its forms .... I have an example from my daughter, who now goes to the 4 th grade ... She is not so good at spelling, but she has excellent vocabulary, a lot of imagination and oral fluency. She also draws quite well. When she drew a "board", she was seriously concerned with how to write the title, that is, with the correct spelling, but on the contrary, she was not interested in learning the spelling assigned for the next day in order to get a good mark! The sterile repetition of the same spelling has not helped her much so far ... Teachers should eventually have to attend compulsory language teaching seminars ... By the way, if I can express my complaint ... When our little ones from kindergarten go to primary school, teachers treat them like students of High School! Sitting behind the chair, stern, distant ... Without a caress, a hug, a kiss ... When the kids "move up" in the school system they change, they transform. They get tougher, more competitive, I think, and it's not just the fact that they're getting older...(KT14).

\section{First-grade teacher's results of open-ended question (2nd part): How integration could (or not)} optimize the approach to language teaching at both levels

The responses of first-grade teachers to the integration of kindergarten and first-grade curricula and how it could optimize (or not) the approach to language teaching at both levels, although numerically fewer than those of kindergarten teachers, are interesting.

First-grade teachers who believe that integration could optimize the approach to language teaching at both levels (Table 9) referred to:

Table 9. How the integration could optimize the approach language (PT)

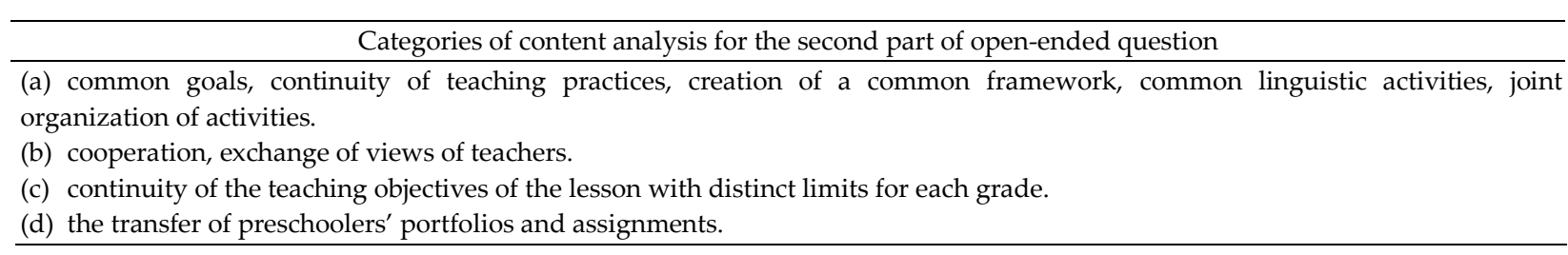

They referred to the close cooperation between kindergarten teachers and school teachers as well as to the primary and high school cooperation (b) in a single teaching framework (a):

An effective collaboration could exist between kindergarten and primary school on a curriculum basis, as long as it is institutionalized. There should be similar cooperation between primary school and high school (PT1),

I think that the collaboration of teachers and kindergarten teachers is very important as kindergarten teachers could benefit from the theoretical background of teachers, while teachers from the playful forms of teaching introduced by kindergarten (PT2).

They also mentioned the continuity (c) that can be secured by the integration of the two curricula, in particular, a first-grade teacher refer:

a) Students' preparation and first contact with writing should be done in kindergarten, so that they can proceed smoothly to learning to read and write, b) They will not be taught the same things, which is boring for them, but will continue from where they left off, c) Inevitably, some children learn from their family to write before 1st grade, so there is a gap between the children who know how to write and those who do not; therefore we have a twospeed class, so integration would help avoid this situation. It could help immature children before entering primary school and experience failure (PT3).

A first-grade teacher refer to the collaboration of teachers very characteristically:

Teachers should be aware of the curricula of both levels at an early stage. Then it would be possible to integrate so that first-grade teachers would continue the work of kindergarten teachers and not start from scratch (PT4).

First-grade teachers who believe that integration could not optimize the approach to language teaching at both levels of the two curricula (Table 10) refer to:

Table 10. How the integration could not optimize the approach language (PT)

Categories of content analysis for the second part of open-ended question

(a) the different developmental level and the different learning abilities of kindergarten and first-grade children.

(b) the different approach to language teaching, the differentiation of the objectives of the curricula and the way the kindergarten and primary school function, the different learning goals and 'different interests, even between two very close ages, different linguistic and mental maturity'. 
(c) the different roles of two school, emfisizing at the socialization character of kindergarten and expressing their fear about its schoolarization.

(d) protection of their labor rights.

They refer to the different objectives of the two curricula ( $a$ and $b$ ):

I disagree with the integration of the curricula of kindergarten and first-grade primary school because the learning process in kindergarten is more playful, while in primary school it becomes more "serious", as it is the stepping stone for the student's entrance into the school environment. I also think that the integration of the curriculum of the first two grades of primary school is not feasible since the child intended for first-grade does not have the maturity to meet the teaching objectives of the second grade (PT5).

One teacher's response (a and c):

The kindergarten places or should place a greater emphasis on the socialization of the pupils, the receptivity of the new, the group. It cannot be integrated with first-grade because I believe the child will this way be going backwards, due to his/her age. The first-grade is the next step in the ladder. The kindergarten has to feed the horse and the primary school has to urge it to run (PT6)

is typical.

Some teachers are critical of kindergarten literacy work (b and c):

Kids in kindergarten are not prepared at all with prewriting exercises. In many cases they cannot even spell their name. So these must be done in the first days of primary school. So students are pressured from the beginning to learn too much. These must therefore be taught in kindergarten so that there is continuity in the curriculum for both levels (PT7).

They refer to the different roles of the two schools (c):

The role of the kindergarten is not the same as the role of primary school. The one or two-year age difference of these children is crucial with regard to their abilities. The difference in their capabilities also dictates different goals in the curriculum (PT8).

They express their concern about the schoolarization of the kindergarten (c):

I think that with this integration there will be a lot of knowledge and concepts that will have to be taught to children from a very early preschool age. In the effort to get students to acquire all this knowledge, I think there will be stress and pressure to obtain the knowledge required. But what is the goal in the end, the range of knowledge or learning in an enjoyable way? (PT9).

Finally, first-grade teachers express their concerns about their labor rights, but also the confusion that may arise concerning the work of kindergarten and school teachers (d):

I think that there has to be relevance, but there is no need to integrate the curriculum because if that happens, on the one hand, kindergarten teachers are given the opportunity to teach in primary school and teachers to teach in kindergarten (which is not right for any of our labor rights), and on the other hand, I find that the teaching approach is very different in kindergarten compared to primary school. Primary school curriculum should come as a continuation of kindergarten curriculum and not identify with it (PT10).

\section{Conclusion and Discussion}

The research questions concern the perceptions of kindergarten and first-grade teachers about the need to integrate the two curricula on the language learning area and ways to optimize the approach to language teaching at both levels in the context of integration or their reasons to disagree with it.

The findings lead to the following conclusions: From the findings of the closed-ended question, first-grade teachers appear to be more positive, compared to kindergarten teachers, on integrating the two curricula. This differentiation seems to reflect their general pedagogical beliefs, their philosophy as well as their teaching practices. However, both kindergarten and first-grade teachers seemed to view positively the possibility of cooperation, exchange of views and work, joint organization of activities in the linguistic field, to form the bridge between the two levels; common goals, the (educational) continuity of teaching practices, the creation of a common framework, the transfer of student files and work. These findings are in line with Greek and international research findings (see: Ackesjö, 2013; Alatalo et al., 2017; Broström, 2007; Byrnes and Wasik, 2019; Dockett and Perry, 2007; Karydis, 2014; Sivropoulou and Vrinioti, 2009; Zeegers, 2012; Zhu, 2010). In particular, in the context of information, co- 
education, cooperation and exchange of views, the adaptation and co-creation of theoretical principles and teaching practices under a common practice could be encouraged (Alatalo et al., 2017; Djonov et al., 2018; EACEA, 2011; WEF, 2000; Zeegers, 2012; Zhu, 2010).

From the findings of the open-ended question and accordingly to international studies (Ackesjö, 2013; Alatalo, Meier and Frank, 2016; Cruickshank and Haefele, 2001; Hjelte, 2005; Karydis, 2014) our findings stated that kindergarten and first-grade teachers refer to the reasons of their aggrement (common goals, common activities, cooperation, smooth transition, continuity) or disagreement (schoolarization, different growth rate, diffeent curricula, different goals) with the inegration of the two curricula. First-grade teacher's responses at the 2nd part of the open-ended question explain their agreement or disagreement more specifically, as they seemed to be significantly influenced by the burden of the responsibility for language teaching (Barrett et al., 2007; Byrnes and Wasik, 2019; Djonov et al., 2018; EACEA, 2011; Hanemann, 2015, 2019; Hanemann and Krolak, 2017; Kennedy et al., 2012; Xue and Meisels, 2004) and to be critical of the results of the 'teaching' of kindergarten teachers, considering it merely as a basis and a reinforcing element for the systematic teaching and substantive work of the primary school. Their answers suggest a view of the role of kindergarten as an earlier stage of preparing children for the first-grade of primary school rather than as an autonomous stage of building knowledge to be then used in primary school (Hidi and Boscolo, 2006; Morris, Tyner and Perney, 2000; Neuman et al., 2000; NICHD, 2005). They expressed the view that the kindergarten operates at a different 'lower level'. The fact that children come from different kindergartens that taught different things (due to the lack of a common textbook) makes it difficult for them to detect what children know, so they do not use students' prior knowledge in their teaching. Kindergarten teachers who disagree with integration explain their disagreement as strongly express the fear of a schoolarization of kindergarten and the loss of the emergent, free and spontaneous nature of literacy in the kindergarten (DEECD, 2009; Paris, Byrnes and Paris, 2001; Wasik et al., 2006). Some researchers (see for example: Ring and O'Sullivan, 2018) call the global trend of preparing children for school by prescribed curriculum 'an epidemic'. But, accordingly to Ackesjö and Persson (2019), the process of schoolarization on one hand tends to narrow the aim of the preschool class to a focus on isolated learning outcomes for children and on the other hand, it may create a sense of wholeness in the educational system as the preschool class moves closer to, and becomes a clear part of, primary school. In line with these findings (Ackesjö and Persson, 2016, 2019; Broström, 2017; Sahlberg, 2016) our kindergarten teachers seem to exprees their fear that pedagogical integration and the introduction of the preschool pedagogy into school education could be replaced by more schooloriented, knowledge-economy arguments that emphasize increased goal achievement. However, firstgrade teachers who disagree with integration insist on the inability of preschoolers to acquire knowledge intended to be acquired by primary school children, who are theoretically in the age group with the relative cognitive, mental and emotional maturity (Ackesjö and Persson, 2016, 2019; O'Sullivan, 2005; Silva Joyce and Feez, 2016; Wasik et al., 2006; Xue and Meisels, 2004).

Morever, both kindergarten and first-grade teachers, at the 2nd part of the open-ended question, emphasize the need for co-operation, but not integration, as even those who agree delineate and define it within a specific context. They are concerned about how integration will take place and propose common goals and teaching approaches that will be governed by continuity and consistency. In line with lifelong learning literacy theory (Djonov et al., 2018; EACEA, 2011; Hanemann, 2015, 2019; Hanemann and Krolak, 2017; Kennedy et. al., 2012; Silva Joyce and Feez, 2016; UIL, 2010, 2017, 2018; UNESCO, 2005, 2007, 2015, 2017; Xue and Meisels, 2004) the issue of enhancing child literacy has been one of the most important factor for subsequent school success or failure of the child and therefore contributing in the long run to social well-being, social justice and the development of democracy (UNESCO, 2005, 2007, 2015, 2017). They want to keep the game as the primary teaching and learning tool in kindergarten and systematic teaching with elements of the playful kindergarten learning system in the primary school (O'Sullivan, 2005; Silva Joyce and Feez, 2016; Xue and Meisels, 2004; Xefteri, 2017). Their answers, in line with international research findings (see for example: Hurst and Reding, 2000; Keely, Smith and Buskist, 2006; Kramer, 2003; Stronge, 2002; Xefteri, 2017), show the professionalism and conscientiousness with which they practice the teaching profession. It is surprising that, while referring to change and the 
creation of an integrated framework, few consider their need for continuous and systematic training on contemporary teaching matters, although it is a widespread demand of teachers (Hanemann and Krolak, 2017; Silva Joyce and Feez, 2016; Zeegers, 2012; Zhu, 2010).

We consider that this study provided valuable insights into how preschool and first-grade of primary school teachers made sense of the possible integration of the two curricula. The results could constitute the pillars for institutionalizing a more co the goal is to have continuity through a balanced literacy curriculum and smooth transition of children to elementary school. The results could be the pillars for establishing a framework that could function as a bridge between kindergarten and primary school with obvious positive outcomes for young students, teachers and the school community at large. According to the basic goal of CTC for kindergarten (MoE/PI 2002b) and PTG (Dafermou et al., 2006), preschool education is an integral part of our educational system and therefore national planning of a structured transition from kindergarten to primary school seems more important than ever.

\section{Declarations}

Acknowledgements: Not applicable.

Authors' contributions: Study concept and design: Both of the authors. Analysis and interpretation of data: Author 1. Drafting of the manuscript: Author 1. Critical revision of the manuscript for important intellectual content: Author 2. Statistical analysis: Author 1. Study supervision: Author 2.

Competing interests: The authors declare that they have no competing interests.

Funding: Not applicable.

\section{References}

Ackesjö, H. (2013). Children crossing borders: School visits as initial incorporation rites in transition to preschool class. International Journal of Early Childhood, 45, 387-410. https://doi.org/10.1007/s13158-013-0080-7

Ackesjö, H., \& Persson, S. (2016). The educational positioning of the preschool-class at the border between social education and academic demands - An issue of continuity in Swedish early education? Journal of Education and Human Development, 5(1), 182-196. https://doi.org/10.15640/jehd.v5n1a19

Ackesjö, H., \& Persson, S. (2019). The schoolarization of the preschool class - policy discourses and educational restructuring in Sweden. Nordic Journal of Studies in Educational Policy, 5(2), 127-136. https://doi.org/10.1080/20020317.2019.1642082

Aidinis, A., \& Grollios, G. (2007). Critical remarks in the new book of the first grade language lesson of the elementary school. Antitetradia tis ekpaidefsis, 85, 35-42.

Aidinis, A., \& Nunes, T. (2001). The role of different levels of phonological awareness in the development of reading and spelling in Greek. Reading and Writing, 14, 145-177. https://doi.org/10.1023/A:1008107312006

Alahiotis, S. (2002). Towards a modern school. Ministry of Education/Pedagogical Institute. 4 May 2017 retrieved from http://www.pi-schools.gr/download/programs/depps/s alax diathematikotita.pdf

Alatalo, T., Meier, J., \& Frank, E. (2016). Transition between Swedish preschool and preschool class: A question about interweaving care and knowledge. Early Childhood Education Journal, 44(2), 155-167.

Alatalo, T., Meier, J., \& Frank, E. (2017). Information sharing on children's literacy learning in the transition from Swedish preschool to school. Journal of research in childhood education, 31(2), 240-254. https://doi.org/10.1080/02568543.2016.1274926

Barrett, A., Sajid, A., Clegg, J., Hinostroza, J., Lowe, J., Nikel, J., ... Yu, G. (2007). Initiatives to improve the quality of teaching and learning: A review of recent literature. Background paper prepared for the Education for All global monitoring report 2008. UNESCO. 4 May 2017 retrieved from http://unesdoc.unesco.org/images/0015/001555/155504e.pdf

Bredekamp, S., \& Copple, C. (1997). Developmentally Appropriate Practice in Early Childhood Programs (Revised Edition). Washington, DC: NAEYC.

Broström, S. (2002). Communication and continuity in the transition from kindergarten to school. In H. Fabian \& A.-W. Dunlop (Eds.) Transitions in the early years. Debating continuity and progression for children in early education (pp.52-63). London and New York: Routledge Falmer.

Broström, S. (2007). Transitions in children's thinking. In A.-W. Dunlop \& H. Fabian (Eds.) Informing transitions in the early years. Research, policy and practice (pp. 61-73). Maidenhead: McGraw-Hill/Open University Press.

Broström, S. (2017). A dynamic learning concept in early years' education: A possible way to prevent schoolification. International Journal of Early Years Education, 25(1), 3-15. https://doi.org/10.1080/09669760.2016.1270196 


\section{Zoi APOSTOLOU \& Nektarios STELLAKIS}

Bryman, A. (2017). Methods of social research. Athens: Gutenberg.

Byrnes, J. P., \& Wasik, B. A. (2019). Language and literacy development: What educators need to know (2nd ed.). New York: The Guilford Press.

Cohen, L., \& Manion, L. (2008). Educational research methodology. Athens: Metehmio.

Cohen, L., Manion, L., \& Morrison, K. (2007). Research methods in education. London and New York: Routledge Falmer. https://doi.org/10.4324/9780203029053

Comber, B., \& Nichols, S. (2004). Getting the big picture: Regulating knowledge in the early childhood literacy curriculum. Journal of early childhood literacy, 4(1), 43-63. https://doi.org/10.1177/1468798404041455

Creswell, J. W. (2016). Research in education: Planning, conducting and evaluating quantitative and qualitative research. Athens: Ion.

Cruickshank, D., \& Haefele, D. (2001). Good teachers, plural. Educational leadership, 58(5), 26-30.

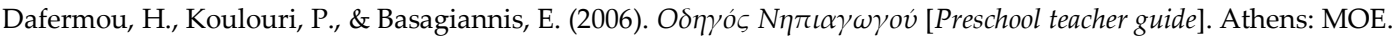

Department of Education and Early Childhood Development. (2009). Transition: A positive start to school. State Government of Victoria. 4 May 2017 retrieved from https://www.education.vic.gov.au/Documents/childhood/providers/edcare/evirefpracpdf

Djonov, E., Torr, J., \& Stenglin, M. (2018). Early language and literacy: Review of research with implications for early literacy programs at NSW public libraries. Sydney: Department of Educational Studies, Macquarie University.

Dockett, S., \& Perry, B. (2007). Transitions to school: Perceptions, expectations, experiences. Sydney: University of New South Wales Press.

Education, Audiovisual and Culture Executive Agency. (2011). Teaching Reading in Europe: Contexts, Policies and Practices. P9 Eurydice. 18 July 2019 retrieved from http://eacea.ec.europa.eu/education/eurydice

European Commission. (2019). Organization of the education system in Greece 2009/2010. Eurydice. 4 January 2020 retrieved from https://eacea.ec.europa.eu/national-policies/eurydice/content/organisation-education-system-and-its-structure-33en

Fabian, H., \& Dunlop, A.-W. (Eds.) (2006). Transitions in the early years. Debating continuity and progression for children in early education ( $3^{\text {rd }}$ ed.). London and New York: Routledge Falmer.

Frank-Oputu, E. A., \& Oghenekohwo, J. E. (2017, April). Literacy education and sustainable development in developing societies. International Journal of Education \& Literacy Studies, 5(2), 126-131. https://doi.org/10.7575/aiac.ijels.v.5n.2p.126

Giannikopoulou, A. (2001). P Like Pokemon: Familiarizing children with letters in a two alphabet society. In Papoulia-Tzelepi, P. (Ed.), The emergence of literacy: Research and practice (pp. 169-195). Athens: Kastaniotis.

Hall, K. (2013). Effective literacy teaching in the early years of school: A review of evidence. In J. Larson \& J. Marsh (Eds.) The SAGE handbook of early childhood literacy (pp.523-540). London: Sage. https://doi.org/10.4135/9781446247518.n29

Hanemann, U. (2015). Lifelong literacy: Some trends and issues in conceptualizing and operationalizing literacy from a lifelong learning perspective. International Review of Education. Journal of Lifelong Learning, 61(3), $295-326$. https://doi.org/10.1007/s11159-015-9490-0

Hanemann, U. (2019). Examining the application of the lifelong learning principle to the literacy target in the fourth Sustainable Development Goal (SDG 4). International Review of Education, 65, 251-275. https://doi.org/10.1007/s11159-019-09771-8

Hanemann, U., \& Krolak, L. (2017). Fostering a culture of reading and writing. Examples of dynamic literate environments. Selected case studies from UNESCO's Effective literacy and numeracy practices database (LitBase). Hamburg: UNESCO Institute for Lifelong Learning. 4 February 2018 retrieved from http://unesdoc.unesco.org/image s/0025/00257 9/25793 $\underline{\text { 3e.pdf }}$

Hasan, R. (2006). Literacy, speech and society. In A. Charalampopoulos (Ed.), Literacy, Society and Education. Thessaloniki: Institute of Modern Studies, Manolis Triantafyllidis Foundation.

Heath, S. B. (2009). Ways with words. Cambridge: Cambridge University Press.

Hidi, S., \& Boscolo, P. (2006). Motivation and writing. In C. A. MacArthur, S. Graham \& J. Fitzgerald (Eds.), Handbook of writing research (pp. 144-157). New York: Guilford Press. https://doi.org/10.1163/9781849508216

Hindman, A. H., \& Wasik, B. A. (2011). Exploring Head Start teachers' early language and literacy knowledge: Lessons from the excel PD intervention. NHSA Dialog: A Research-to-Practice Journal for the Early Intervention Field, 14(4), 93-315. https://doi.org/10.1080/15240754.2011.617528

Hjelte, J. (2005). Cooperation in the border country: About the relationships and communication in collaboration between schools and childcare. Umeå: Umeå Universitet Press.

Hurst, B., \& Reding, C. (2000). Professionalism in teaching. Upper Saddle River, NJ: Prentice Hall.

Iosifidis, T. (2003). Analysis of qualitative data in the social sciences. Athens: Review. 
Teachers' perceptions of integrating kindergarten...

Karydis, I. (2014). Exploring the views of kindergarten and teachers on the transition from kindergarten to elementary school: A comparative approach (Unpublished master thesis). University of Ioannina, Ioannina.

Keeley, J., Smith, D., \& Buskist, W. (2006). The teacher behaviors checklist: Factor analysis of its utility for evaluating teaching. Teaching of Psychology, 33(2), 84-91. https://doi.org/10.1207/s15328023top3302_1

Kennedy, E., Dunphy, E., Dwyer, B., Hayes, G., McPhillips, T., Marsh, J., ... Shiel, G. (2012). Literacy in early childhood and primary education (3-8 years) (Research Report No. 15). National Council for Curriculum and Assessment. 4 February 2018 retrieved from https://ncca.ie/media/2137/literacy_in_early_childhood_and_primary_education_3-8_years.pdf

Kondyli, M., \& Stellakis N. (2006). Literacy practices in pre-primary education: A program, two approaches. In P. PapouliasTzelepi, A. Fterniatis and K. Thivaios (Eds.) Research and practice of literacy in Greek society (pp. 159-180). Athens: Ellinika Grammata.

Koustourakis, G. (2014). A sociological approach to painting teaching according to the contemporary Greek kindergarten curriculum. The International Journal of the Early Childhood Learning, 20(1), 23-37. https://doi.org/10.18848/23277939/CGP/v20i01/48408

Kramer, P. (2003). The ABC's of professionalism. Kappa Delta Pi Record, 40(1), 22-25. https://doi.org/10.1080/00228958.2003.10516409

Matsagouras, H. (2007). School programming: Functional, critical and scientific. Athens: Grigoris.

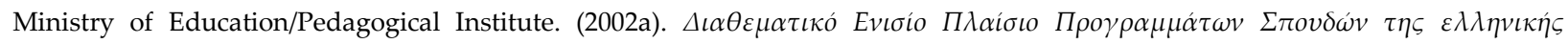

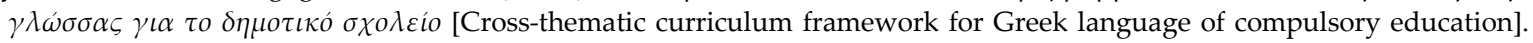
Athens: MOE.

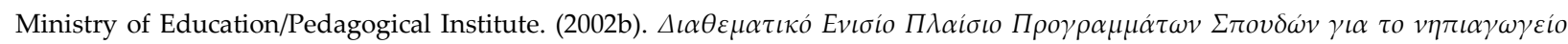
[Cross-thematic curriculum framework for kindergarten]. Athens: MOE.

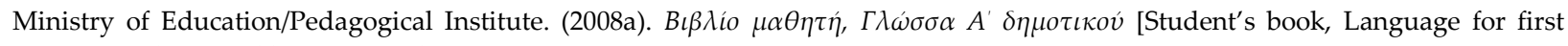
grade ( $a^{\prime}$ and $b^{\prime}$ issue)]. Athens: MOE.

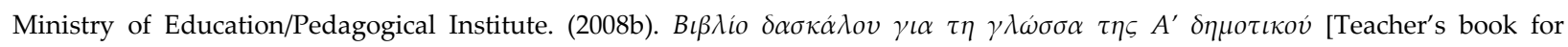
teaching language in first grade]. Athens: MOE.

Morris, D. (2015). Preventing early reading failure: An argument. The Reading teacher, 68(7), 502-509. https://doi.org/10.1002/trtr.1346

Morris, D., Tyner, B., \& Perney, J. (2000). Early Steps: Replicating the effects of a first-grade reading intervention program. Journal of Educational Psychology, 92(4), 681-693. https://doi.org/10.1037/0022-0663.92.4.681

National Institute of Child Health and Human Development Early Child Care Research Network. (2005). Pathways to reading: The role of oral language in the transition to reading. Developmental Psychology, 41(2), 428-442. https://doi.org/10.1037/0012$\underline{1649.41 .2 .428}$

Neuman, S. B., Snow, C. E., \& Canizares, S. E. (2000). Building language for literacy. New York: Scholastic.

Neves, I., \& Morais, A. (2001). Texts and contexts in educational systems: Studies of recontextualising spaces. In A. Morais, I. Neves, B. Davies \& H. Daniels (Eds.), Towards a Sociology of Pedagogy. The Contribution of Basil Bernstein to Research (pp. 223249). N.Y.: Peter Lang.

O'Sullivan, M. (2005). What is happening in the classroom? A common-sense approach to improving the quality of primary education in developing countries. Teacher Development, 9(3), 301-314. https://doi.org/10.1080/13664530500200270

Papoulia-Tzelepi, P. (2001). The emergence of literacy: Research and practice. Athens: Kastaniotis.

Paris, S. G., Byrnes, J. P., \& Paris, A. H. (2001). Constructing theories, identities, and actions of self-regulated learners. In B. Zimmerman \& D. Schunk (Eds.), Selfregulated learning: Theories, research, practice (2nd ed., pp. 253-287). New York: Guilford Press.

Pearson P. D., Raphael T. E., Benson V. L., \& Madda C. L. (2007). Balance in comprehensive literacy instruction: Then and now. In B. G. Linda, L. M. Morrow \& M. Pressley (Eds.), Best Practices in Literacy Instruction (3 ${ }^{\text {rd }}$ ed., pp.30-56). New York: Guilford Publications.

Porpodas, K. (2002). Reading. Patras: Self-publishing.

Powell, D. R., Diamond, K. E., Bojczyk, K. E., \& Gerdel, H. K. (2008). Head start teachers' perspectives on early literacy. Journal of Literacy Research, 40(4), 422-460. https://doi.org/10.1080/10862960802637612

Pressley, M. (2002). Reading instruction that works: The case for balanced teaching (2nd ed). New York: Guildford Press.

Ring, E., \& O'Sullivan, L. (2018). Dewey: A panacea for the 'schoolification' epidemic. Education 3-13, 46(4), 402-410. https://doi.org/10.1080/03004279.2018.1445474

Robson, C. (2010). Real world research: A tool forsocial scientists and professional researchers. Athens: Gutenberg. 


\section{Zoi APOSTOLOU \& Nektarios STELLAKIS}

Sahlberg, P. (2016). The global educational reform movement and its impact on schooling. In K. Mundy, A. Green, B. Lingard \& A. Verger (Eds.), The handbook of global education policy (pp. 128-144). Chichester, West Sussex, UK: John Wiley \& Sons, Ltd. https://doi.org/10.1002/9781118468005.ch7

Scull, J., Nolan, A., \& Raban, B. (2013). Young learners: interpreting literacy practice in the preschool years. Australian Journal of Language and Literacy, 36(1), 38-47.

Silva Joyce, H. and Feez, S. (2016). Exploring literacies theory, research and practice. England: Research and Practice in Applied Linguistics. https://doi.org/10.1057/9781137319036

Sivropoulou, I., \& Vrinioti, K. (2009). Early literacy in transition from pre-school to primary school: Connecting curricula. 4 February 2018 retrieved from http://www.easeeu.com/documents/compendium/chapter10.pdf

Snow, C., Burns, M. S., \& Griffin, P. (1998). Preventing reading difficulties in young children. Washington, DC: National Academy Press.

Sofou, E., \& Tsafos, V. (2009). Preschool teachers' understandings of the national preschool curriculum in Greece. Early Childhood Education Journal, 37(5), 411-420. https://doi.org/10.1007/s10643-009-0368-2

Strickland, D. S., \& Shanahan, T. (2004). Laying the groundwork for literacy. Educational Leadership, 61(2), 74-77.

Stronge, J. (2002). Qualities of effective teachers. Alexandria, VA: Association for Supervision and Curriculum Development.

Tafa, E. (2001). Reading and writing in preschool education. Athens: Ellinika Grammata.

UNESCO Institute for Lifelong Learning (2010). Belem framework for action: Harnessing the power and potential of adult learning and education for a viable future. Hamburg: UIL. 12 February 2018 retrieved from https://unesdoc.unesco.org/ark:/48223/pf0000181414

UNESCO Institute for Lifelong Learning. (2017). Literacy and numeracy from a lifelong learning perspective (UIL Policy Brief 7). Hamburg: UIL. 4 May 2019 retrieved from http://unesdoc.unesco.org/image s/0024/00247 0/24709 4E.pdf

UNESCO Institute for Lifelong Learning. (2018). Recognition, validation and accreditation of youth and adult basic education as a foundation of lifelong learning. Hamburg: UIL. 4 May 2019 retrieved from http://unesdoc.unesco.org/ark:/48223/pf000 02636 19.pdf

United Nations Educational, Scientific and Cultural Organization. (2004). The plurality of literacy and its implications for policies and programmes. (UNESCO Education Position Paper). Paris: UNESCO. 4 May 2019 retrieved from http://unesdoc.unesco.org/images/0013/001362/136246e.pdf

United Nations Educational, Scientific and Cultural Organization. (2005). Aspects of Literacy Assessment. Topics and Issues from the UNESCO Expert Meeting. Paris: UNESCO. 18 May 2019 retrieved from https://unesdoc.unesco.org/ark:/48223/pf0000140125

United Nations Educational, Scientific and Cultural Organization. (2007). Literacy Initiative for Empowerment (LIFE) 2006-2015: Vision and Strategy Paper (3rd ed.). Hamburg: UNESCO Institute for Lifelong Learning. 18 May 2019 retrieved from https://unesdoc.unesco.org/ark:/48223/pf0000141177

United Nations Educational, Scientific and Cultural Organization. (2015). Education for All 2000-2015: Achievements and Challenges. Paris: UNESCO. 18 May 2019 retrieved from https://en.unesco.org/gem-report/report/2015/education-all-2000-2015achievements-and-challenges

United Nations Educational, Scientific and Cultural Organization. (2017) Reading the past, writing the future. Fifty years of promoting literacy. 4 May 2019 retrieved from http://www.unesco.org/new/fileadmin/MULTIMEDIA/HQ/ED/pdf/unesco-promotingliteracy-over-five-decades-en.pdf

Wasik, B. A., Bond, M. A., \& Hindman, M. A. (2006). The effects of a language and literacy intervention on Head Start children and teachers. Journal of Educational Psychology, 98(1), 63-74. https://doi.org/10.1037/0022-0663.98.1.63

World Education Forum. (2000) The Dakar framework for action. Education for all: Meeting our collective commitments. Paris: UNESCO. 18 May 2019 retrieved from http://unesdoc.unesco.org/images/0012/00121 1/12114 7e.pdf

Xefteri, E. (2017). Elementary school literacy using alternative approaches: A teaching intervention based on the top-down teaching model (Unpublished doctorate thesis). Aristotle University of Thessaloniki, Thessaloniki.

Xue, Y., \& Meisels, S. J. (2004). Early literacy instruction and learning in kindergarten: Evidence from the early childhood longitudinal study - kindergarten class of 1998-1999. American Educational Research Journal, 41(1), 191-229. https://doi.org/10.3102/00028312041001191

Zeegers, Y. (2012). Curriculum development for teacher education in the southern Philippines: A simultaneous process of professional learning and syllabus enhancement, International Journal of Educational Development, 32(2), 207-213. https://doi.org/10.1016/j.ijedudev.2011.01.015

Zhu, H. (2010). Curriculum reform and professional development: A case study on Chinese teacher educators, Professional Development in Education, 36(1-2), 373-391. https://doi.org/10.1080/19415250903457604 